\title{
Review on Parasites of Fish and their Public Health Importance
}

\author{
Wondimu Tessema \\ College of Agricultural Science, Department of Animal Science, Arba Minch University, Ethiopia \\ *Corresponding Author: Wondimu Tessema, College of Agricultural Science, Department of Animal \\ Science, Arba Minch University, Ethiopia.
}

\begin{abstract}
The main objective of this review is to know the parasitic fish disease and its public health significance. Fish have a full range of diseases like all animals and many of these are due to external agents and other arises internally. External agents that cause fish disease include viruses, bacteria, fungi and parasites are known to affect fish while internally they suffer from almost all the common organic and degenerative disorders. Parasitic infestation frequently occurs in fish that causes retarded growth rate, reduced production, consumer rejection, low reproduction and mass mortality in fish. There are many parasitic diseases of fishes in the world. Some of the parasitic diseases are protozoans, trematodes, nematodes, cestodes, acanthocephalans, parasitic crustaceans, and leeches. Fish parasites cause commercial losses in both the aquaculture and fisheries industries and may have human health, as well as socioeconomic, implications both in developing and developed countries. Many marine and freshwater fishes serve as a source of medically important parasitic zoonoses that include trematodiasis, cestodiasis, and nematodiasis. Some of these infections are highly pathogenic and the diseases mainly acquired through eating raw or under cooked fish. To overcome negative effect on fish and public health, it is necessary to act upon every health constraint based on scientifically proven and recommended as well as locally applicable ways.
\end{abstract}

Keywords: Fish, Endo-parasite, Ecto-parasite, protozoa, Ethiopia

\section{INTRODUCTION}

Parasitic diseases of fish are of particular importance in the tropics. Parasites usually exist in equilibrium with their host as a survival strategy. However, in instances where hosts are overcrowded such as in aquaria or in fish farms, parasitic diseases can spread very rapidly causing high mortality. Although, this is usually not the case in the wild natural aquatic environments, it occurs when the environment is disturbed by human activity and interference especially with populations which alter the natural distribution of their parasite communities (Imam and Dewu, 2010).

There are a number of different ways that fish can be parasitic. Some species are free-living as adults but have parasitic eggs or larvae, whereas other species such as lamprey, only become parasitic as adults, and there are some such as pearl fish which are parasitic for their entire lives. However, they all share a feature which they have in common with all parasites - they are dependent upon their hosts to complete their life cycle, which is a key feature of parasitism. It should not be surprising that some of the adaptations which have evolved in these fish

ARC Journal of Animal and Veterinary Sciences share parallels with more traditional parasites as they face similar challenges when establishing on or in their host; these selection pressures have led to evolutionary convergence in morphology and function in different parasite taxa (Poulin, 2011).

According to Lemma (2013), many fish diseases are causing huge mortality both in aquaculture and capture fisheries and some are also causing for human diseases in many areas of the world. Several authors also added that some of the detrimental effects of parasites in fish production are causing fish diseases and hence causing mass mortalities, increase farm inputs via increased treatment expenses and cause reduction in growth rate and weight loss during and after the period of parasitic disease outbreak and spoil the appearance of fish and hence lowers the quality and quantity of fish thus resulting in consumer rejection and affect marketability of commercially produced fish in different parts of the country (Gulelat et al., 2013).

To overcome the effects of parasitic infection on fish and public health, it is necessary to act upon every health constraint based on scientifically 
proven and recommended as well as locally applicable ways and also epidemiological approaches needed in keeping aquatic animal health safe (Peeler and Taylor, 2011). Therefore, the Objective of this seminar review is:

$>$ To review the parasites of fish and their public health importance.

\section{LitratURE REVIEW}

\subsection{Parasites of Fish}

Fish have a full range of diseases like all animals and many of these are due to external agents and other arises internally. External agents that cause fish disease include viruses, bacteria, fungi and parasites are known to affect fish while internally they suffer from almost all the common organic and degenerative disorders. Parasitic infestation frequently occurs in fish that causes retarded growth rate, reduced production, consumer rejection, low reproduction and mass mortality in fish (Claude et al., 1998). The most common symptoms of parasitic infestations in fish are weight loss, disruption of reproduction or impotency, blindness, abnormal behavior, epithelial lesions, deformities of gills and others. These all eventually cause an economic loss in the fish farming sector and hence parasites are among the important factors responsible for production losses but fish parasites may be present in or on fish in subclinical state or carrier state and do not always cause disease in fish (Barber, 2007).

Parasites are divided into two distinct groups: ectoparasites and endoparasites. Within these two groups they are categorized by parasite type according to the physical characteristics of the parasite, life cycle, and host infection site. Some examples of these parasite types include fungi and algae, protozoans, trematodes, nematodes, cestodes, acanthocephalans, parasitic crustaceans, and leeches. Parasites can range in body size from small, microscopic organisms like bacteria and single celled organisms to large organisms such as tapeworms and copepods (Roberts and Janovy, 2005).

\subsubsection{Endoparasites}

The internal parasites of fish may in general be classified as flukes (Trematodes), tapeworms (Cestodes), spiny-headed worms (Acanthocephalans) and round worms (Nematodes). These parasites are found in the body cavity, intestines, and various internal organs and sometimes in the flesh. They seldom seriously affect the health of the fish unless present in large numbers (Darwin and Stefanich, 1996).

The helminth parasites that infect vertebrates belong to two phyla, the Platyhelminthes (flatworms) and the Nemathelminthes (roundworms). Flatworms of the class Monogenea are ectoparasitic on the gills and skin of the host while the flukes (Trematoda: Digenea), the tapeworms (Cestoda) and the nematodes infect the internal organs, with their intemediate stages sometimes encysting in various host tissues. In general, the endoparasitic helminths have a heteroxenous life cycle, i.e. one in which the parasite passes through at least one intermediate stage before developing into the adult (Roberts and Janovy, 2000).

\section{Trematodes}

The class trematoda comprises of monogeneans and the digeneans. Monogenean trematodes are also referred to as flatworms or flukes (Klinger and Floyd, 2002) and commonly invade the gills, skin and fins of freshwater and blackish water fish from most families of Teleostei (Whittington et al. 2000).

Monogeneans have direct life cycles (no intermediate hosts) and are host and size specific (Klinger and Floyd, 2002) throughout their distribution range (FAO, 1996).

\section{Cestodes}

Cestodes also called tapeworms are ribbon like flat worms. They infect the alimentary tract, muscle or other internal organ of fish. The clinical sign when fish is affected by cestode parasite are variable degree of dropsy, distended abdomen and reduced in activity. Cestoda are all endoparasites of vertebrates with over 5000 species so far described. Most of them require at least one intermediate host and complete their life cycle as adults in the definitive hosts. Two life cycle stages are represented in fish: adults inhabit the intestine, and plerocercoid larvae of the same or different species are found in the viscera and musculature; the first-stage larvae (procercoids) are generally found in aquatic crustaceans (Woo, 1995).

\section{Nematodes}

The phylum Nematoda is one of the most common phyla of animals with over 80,000 different described species of which over 15,000 are parasitic and diffused in freshwater, marine and terrestrial environments. The phylum contains both free-living organisms and 
parasites of plants and animals, including fish. They are also called roundworms, as they have an elongated, cylindrical in shape with $1 \mathrm{~mm}$ to $1 \mathrm{~m}$ length and circular in section. Nematodes are unsegmented, bilaterally symmetric with a complete digestive system consisting of three sections: anterior (esophagus), middle (intestine), and posterior (rectum) ending with the anus (Grabda, 1991).

\section{Acanthocephalans}

Acanthocephalans also known as spiny or thorny-headed worms which belong to the separate distinct phylum with about 1200 species divided into three classes namely: Archiacanthocephala, Eoacanthocephala and Palaeacanthocephala. All are intestinal parasites of vertebrates including fish, amphibians, birds and mammals. They are cylindrical worms from few $\mathrm{mm}$ to $70 \mathrm{~cm}$ long with the anterior part provided with an eversible hooked proboscis, without digestive system. They absorb nutritive materials with the whole surface of the body (Grabda, 1991).

\subsubsection{Ectoparasites}

Ecto-parasite infestation is one of the most hazardous threats to fish health. They have been noted by many researchers as a major problem in pond fish culture where high temperature and organic content may accelerate the life cycles of these parasites and promote their spread (Tachia et al., 2010).

Ecto-parasites are parasites that are located on the external surfaces of a host organism. In fish this would include the skin or scales depending on the fish species, fins, and other structures considered external such as gills, gill rakers, and the oral cavity. Clinical signs and symptoms vary with the type and severity of parasite infestation. Most parasites are not harmful to humans but can make fish unappealing to anglers (Roberts and Janovy, 2005).

External parasites of fish are easily seen and consists of four groups of organisms; flukes, leeches (blood suckers), copepods (fish lice) and lampreys. Some cling to the exposed body surfaces or live in the gill chambers, feeding on the body mucus or on blood (Darwin and Stefanich, 1996).

\subsubsection{Protozoan Disease}

Most of the commonly encountered fish parasites are protozoans. They are single-celled organisms, many of which are free-living in the aquatic environment. Their ability to multiply on or within their hosts makes them in many instances very dangerous to fish. They have a direct life cycle and mostly reproduce by binary fussion; some species have cyst form, off the host. Typically, these parasites are present in large numbers either on the surface of the fish, within the gills, or both. The general effect of these parasites is to irritate the epithelial surface, causing an increasing mucus production. There are three main groups of protozoan parasitizing the external tissues of fish: ciliates, flagellates, and amoebae (Chandra, 2004).

\section{Public Health Importance}

A large number of parasites infect fish, but only a few cause illnesses in humans. Many marine and freshwater fishes serve as a source of medically important parasitic zoonoses that include trematodiasis, cestodiasis, and nematodiasis. Some of these infections are highly pathogenic. These diseases are mainly acquired through eating raw or under cooked fish. The reported incidence of these fish-borne zoonoses has increased in recent years due to the development of improved diagnosis, increase in raw fish consumption in those countries in which such dishes have commonly been eaten, increased consumption elsewhere of regional fish dishes based on raw or poorly processed fish, the growth in the international market in fish and fish products, and the remarkable development of aquaculture (Robinson and Dalton, 2009).

\section{CONCLUSION AND RECOMMENDATION}

Fish have a full range of diseases like all animals and many of these are due to external agents and other arises internally. External agents that cause fish disease include viruses, bacteria, fungi and parasites are known to affect fish while internally they suffer from almost all the common organic and degenerative disorders. Parasitic infestation frequently occurs in fish that causes retarded growth rate, reduced production, consumer rejection, low reproduction and mass mortality in fish.

Parasites that affect fish include parasitic protozoans, acanthocephalans, nematodes, digeneans, cestodes and crustaceans which are the most important parasites of fish. Helminths are highly specialized parasites that require specific definitive hosts. They frequently occur within the body cavity and viscera of fish. Due to their location in host fish, they may affect one or more important organ systems. 
As a review a described that large number of parasites infects fish, but only a few cause illnesses in humans. Many marine and freshwater fishes serve as a source of medically important parasitic zoonoses that include trematodiasis, cestodiasis, and nematodiasis. Some of these infections are highly pathogenic. These diseases are mainly acquired through eating raw or under cooked fish. Therefore, based on the above conclusion of review the following recommendation was forwarded:

$\checkmark$ There should be a clear nationwide policy and strategy concerning fish disease prevention and control at large and endo and ecto-parasites in particular.

$\checkmark$ Further comprehensive study on the economic and public health impact of parasites and molecular level characterization of them is recommended.

$\checkmark$ Awareness should be raised about fish born zoonotic parasites and consumers should not eat raw or undercooked fish.

\section{REFERENCES}

[1] Andreassen, J, and Jörring, K., 1970: Anisakiasis in Denmark, Infection with nematode larvae from marine fish, Nord Med 84, 1492-1495 in Danish.

[2] Barber, I., 2007: Parasites, behaviour and welfare in fish, Applied Animal Behaviour Science, 104(3), 251-264.

[3] Bernier, L. M. J., 1986: Liver pathology of burbot Lota lota (Linnaeus) and the parasites Raphidascaris acus (Bloch) and Triaenophorus nodulosus (Pallas) with notes on transmission routes. Arctic Biological Consultants, Winnipeg, MB for Department of Fisheries and Oceans, Winnipeg, MB. 23pp.

[4] Bourree, P, Paugam, A and Petithory, J. C., 1995: Anisakidosis: Report of 25 cases and review of the literature. Comp. Immunol. Microbiol. Infect. Dis. 18, 75-84.

[5] Chandra, K. J., 2004: Fish parasitology. K. R. Choudhury, 34/A/2, Ram Babu Road, Mymensingh-2,200, 196 pp.

[6] Chen, D. Chen, J. Huang, J. Chen, X. Feng, D. Liang, B. Che, Y. Liu, X. Zhu, C. Li, X. and Shen, H., 2010: Epidemiological investigation of Clonorchis sinensis infection in freshwater fishes in the Pearl River Delta. Parasitol. Res. 107: 835-839.

[7] Choi, S. J, Lee, J. C, Kim, M. J, Hur, G.Y, Shin, S.Y, and Park, H. S., 2009: The clinical characteristics of Anisakis allergy in Korea. Kor. J. Intern. Med. 24 (2), 160-163.
[8] Claude, E., Boyd, J. and Craig, S., 1998: Pond Aquaculture water quality management, Kluer Acakemic publisher, U.S.A. Pp. 87-152.

[9] Couture, C, Measures, L, Gagnon, J, and Desbiens, C., 2003: Human intestinal anisakiosis due to consumption of raw salmon. Am. J. Surg. Pathol. 27, 1167-1172.

[10] Darwin, E. J and Stefannich, F. A., 1996: Some common parasites of the fish of Alaska, Division of sport fish Anchorage, ALASKA.

[11] Dickerson, H. W., 2012: Ichthyophthirius multifiliis. In: Patrick, K.B. and Woo, P.T.K. (ed). Fish Parasites Pathobiology and Protection. CABI, Wallingford. Pp. 55-72

[12] FAO, 1996: Parasites, infections and diseases of fishes in Africa - An Update. Committee for Inland Fisheries of Africa (CIFA), Technical Paper No.31. FAO, Rome. 220 pp.

[13] FAO, 2009: The state of world fisheries and aquaculture 2008, Food and agriculture organization of the United Nations, Rome.

[14] FAO, 2016: The State of World Fisheries and Aquaculture, Contributing to food security and nutrition for all, Food and Agriculture Organization of the United Nations, Rome, Italy.

[15] Fumarola, L, Monno, R, Ierardi, E, Rizzo, G, Giannelli, G, Lalle, M and Pozio, E., 2009: Anisakis pegreffi etiological agent of gastric infections in two Italian women. Foodborne Pathog. Dis. 6 (9), 1157-1159.

[16] Gulelat, Y., Eshetu, Y., Asmare, K., Bekele, J., 2013. Study on parasitic helminthes infecting three fish species from Koka reservoir, Ethiopia. SINET: Ethiop. J. Sci. 36, 73-80.

[17] Kagei, N, and Isogaki, H., 1992: A case of abdominal syndrome caused by the presence of a large number of Anisakis larvae. Int. J. Parasitol. 22 (2), 251-253.

[18] Klinger, R. E and Floyd, R. F., 2002: Introduction to Freshwater Fish Parasites. Florida Cooperative Extension Service Institute of Food and Agricultural Sciences. University of Florida. http.//edis.Ifasufl.edu. ,_Accessed 20th June, 2006.

[19] Lemma A., 2013: Study on temporal variation of internal fish parasites in Lake Ziway, Ethiopia. A. J. F. S. 1 (1), 001-004. Available at: www./International, scholar's journals. Org. Fisheries, Accessed date: 13 October 2017.

[20] Li, S. W, Shiao, S. H, Weng, S. C, Liu, T. H, Su, K. E, and Chen, C. C., 2015: A case of human infection with Anisakis simplex in Taiwan. Gastrointest. Endosc. 82 (4), 757-758.

[21] Lin, A. H, Nepstad, I, Florvaag, E, Egaas, E, and Van Do, T., 2014: An extended study of seroprevalence of anti-Anisakis simplex $\operatorname{IgE}$ antibodies in Norwegian blood donors. Scand. J. Immunol. 79 (1), 61-67. 
[22] Mercado, R, Torres, P, Muñoz, V, and Apt, W., 2001: Human infection by Pseudoterranova decipiens (Nematoda, Anisakidae) in Chile: report of seven cases. Mem. Inst. Oswaldo Cruz 96 (5), 653-655.

[23] Mladineo, I, Poljak, V, Martínez-Sernández, V, Ubeira, F. M., 2014: Anti-Anisakis IgE seroprevalence in the healthy Croatian coastal population and associated risk factors. PLoS Negl, Trop. Dis. 8(2), 2673.

[24] Möller, H, and Schröder, S., 1987: Neue Aspekte der Anisakiasis in Deutschland (New aspects of anisakidosis in Germany), Arch. Leb. 38, 123-128 in German.

[25] Na, H. K, Seo, M, Chai, J. Y, Lee, E. K., and Jeon, S. M., 2013: A case of anisakidosis caused by Pseudoterranova decipiens larva, Korean J. Parasitol. 51 (1), 115-117.

[26] Nagasawa, K., 2012: The biology of Contracaecum osculatum sensu lato and $\mathrm{C}$. osculatum A (Nematoda: Anisakidae) in Japanese waters: a review. Biosphere Sci. 51, 61-69

[27] Nieuwenhuizen, N, Lopata, A. L, Jeebhay, M. F, Herbert, D. R, Robins, T. G, and Brombacher, F., 2006: Exposure to the fish parasite Anisakis causes allergic airway hyperreactivity and dermatitis. J. Allergy Clin. Immunol. 117, 1098-1105.

[28] Peeler, E. J and Taylor, N. G., 2011: The application of epidemiology in aquatic animal health -opportunities and challenges, Veterinary Research, vol. 42, no. 1, article no. 94.

[29] Pinkus, G. S, Coolidge, C, and Little, M. D., 1975: Intestinal anisakiasis, First case report from North America. A. J. Med. 59, 114-120.

[30] Poulin, R., 2011: The many roads to parasitism: a tale of convergence. Adv. Parasitol. 74, 1-40.

[31] Repiso, O. A, Alcántara, T. M, González, F. C, de Artaza, V. T, Rodríguez, M. R, Valle Muñoz, J, and Martínez Potenciano, J. L., 2003: Gastrointestinal anisakiasis, Study of a series of 25 patients. Gastroenterol, Hepatol, 26(6), 341346 (In Spanish).
[32] Roberts, L. S. and Janovy, J., 2000: Gerald D. Schmidt and Larry S. Roberts' Foundations of Parasitology, 6th Ed. McGraw-Hill International Editions, Boston.

[33] Roberts, L. S, Janovy J. J., 2005: Foundations of Parasitology (Seventh ed.). New York: McGraw-Hill.

[34] Robinson, M.W. and Dalton, J., 2009: Zoonotic helminth infections with particular emphasis on fasciolosis and other trematodiases. Philos. Trans. R. Soc. Lond. B. Biol. Sci. 364: 27632776.

[35] Schaum, E, and Müller, W., 1967: Heterocheilidiasis (case report). Dtsch. Med. Wochenschr. 92, 2230-2233.

[36] Shamsi, S, and Butcher, A. R., 2011: First report of human anisakidosis in Australia. Med. J. Aust. 194, 199-200.

[37] Skirnisson, K., 2006: Pseudoterranova decipiens (Nematoda, Anisakidaeae) larvae reported from humans in Iceland after consumption of insufficiently cooked fish. Laeknabladid, J. 92, 21-25. (in Icelandic).

[38] Tachia, M. U., Omeji, S. and Odeh, L. 2010. A Survey of ectoparasites of Clariasgariepinus caught from the University of Agriculture Research Fish Farm, Makurdi. J. Res. Fores, Wild. Env.4 (2): 30 - 38.

[39] Van Thiel, P. H, Kuipers, F. C, and Roskam, T. H., 1960: A nematode parasitic to herring, causing acute abdominal syndromes in man. Trop. Geogr. Med. 12, 97-113.

[40] Whittington, I., D., Cribb, B., W., Hamwood, E., and Halliday, J. A., 2000: Host-specificity of monogenean (Platyhelminth) parasites: a role for anterior adhesive areas? International Journal of Parasitology, 30: 305 - 320.

[41] Woo, P. T. K., 1995: Fish Disease and Disorder: Protozoan and Metazoan Infection volume1, CABI international, walling ford, UK. pp: 45- 46.

[42] Yu, J. R, Seo, M, Kim, Y.W, Oh, M. H., and Sohn, W. M., 2001: A human case of gastric infection by Pseudoterranova decipiens larva, Korean J. Parasitol. 39 (2), 193-196.

Citation: Wondimu Tessema. Review on Parasites of Fish and their Public Health Importance. ARC Journal of Animal and Veterinary Sciences. 2020; 6(2):23-27. DOI: https://doi.org/10.20431/2455-2518.0602004.

Copyright: (C) 2020 Authors. This is an open-access article distributed under the terms of the Creative Commons Attribution License, which permits unrestricted use, distribution, and reproduction in any medium, provided the original author and source are credited. 